\title{
Der Wienerwald. Die Großstadt und ihre Komplementärlandschaft
}

\begin{abstract}
Der Wienerwald ist einerseits im geographischen Sinn eine Region als östlicher Ausläufer der Alpen, andererseits eine Imagination, ein ideelles Konstrukt in Wechselbeziehung mit der Großstadt Wien. In diesem Beitrag gehen wir der Frage nach, unter welchen Voraussetzungen und auf welche Weise der Wienerwald als Landschaft, als ein kulturell überformter und symbolisch aufgeladener Raum entstand. Dabei zeigt sich, dass die ästhetische Aufwertung des Wienerwaldgebietes um I80o einsetzte und mehrere bis heute gültige symbolische Konnotationen bereits im Biedermeier festgelegt wurden. Doch der Begriff „Wienerwald“ etablierte sich erst nach der Mitte des I9. Jahrhunderts und erfuhr um die Wende zum 20. Jahrhundert eine weitere politische Ideologisierung. Tourismus, Kunst und Literatur spielen in diesem kollektiven Aneignungsprozess eine zentrale Rolle, aber auch politische Institutionen und private Vereine. Insgesamt ist von einem komplementären Verhältnis zwischen Region und Metropole auszugehen.
\end{abstract}

The Vienna Woods. The Big City and its Complementary Landscape. The Vienna Woods are on the one hand a region in the geographical sense, as the eastern foothills of the Alps, while on the other hand they are an imagined space, an ideal construct in interaction with the city of Vienna. In this paper, we examine under which conditions and in which way the Vienna Woods emerged as a landscape, as a culturally transformed and symbolically charged space. This shows that the aesthetic revaluation of the Vienna Woods area began around I80o, and that several symbolic connotations that have survived to this day were already established in the Biedermeier period. But the term "Wienerwald" did not establish itself until the middle of the $19^{\text {th }}$ century, and underwent further political ideologization around 1900 . Tourism, art and literature play a central role in this collective process of appropriation, as do political institutions and private associations. Overall, a complementary relationship between the region and the metropolis can be assumed.

Keywords: landscape perception, ideologization, urban-rural relationship, environmental history, urban green belts

doi.org/10.52035/noil.2021.19jh02.20

Veröffentlicht nach externer Begutachtung (doppelblind) / published after external peer review (double blind) 